\title{
Selection for Fungicide Resistance Within a Growing Season in Field Populations of Phytophthora infestans at the Center of Origin
}

\author{
Niklaus J. Grünwald, Anne K. Sturbaum, Gaspar Romero Montes, \\ Edith Garay Serrano, Hector Lozoya-Saldaña, and William E. Fry
}

First author: Horticultural Crops Research Laboratory, U.S. Department of Agriculture-Agricultural Research Service (USDA-ARS), 3420 NW Orchard Ave., Corvallis, OR 97330; second author: USDA-ARS, 1691 S. 2700 W, Aberdeen, ID 83210; third, fourth, and fifth authors: Cornell-Eastern Europe-Mexico/Programa Internacional Cooperativo del Tizón Tardío de la Papa Potato Late Blight Project, Apartado postal 3-12, Cuauhtemoc Izcalli V, Metepec, Edo. de México 52176, México; and sixth author: Department of Plant Pathology, Cornell University, 334 Plant Science Building, Ithaca, NY 14853.

Accepted for publication 10 July 2006.

\begin{abstract}
Grünwald, N. J., Sturbaum, A. K., Romero Montes, G., Garay Serrano, E., Lozoya-Saldaña, H., and Fry, W. E. 2006. Selection for fungicide resistance within a growing season in field populations of Phytophthora infestans at the center of origin. Phytopathology 96:1397-1403.

The central highlands of Mexico should provide an optimal testing ground for evaluating the potential threat of selection for resistance to fungicides in the population of Phytophthora infestans. We evaluated the hypotheses that exposure to the fungicides azoxystrobin, cymoxanil, dimethomorph, fluazinam, mancozeb, metalaxyl, and propamocarb hydrochloride would lead to (i) a shift in the sensitivity distributions (i.e., selection) and (ii) a lower genotypic diversity of the population. We
\end{abstract}

ABSTRACT

The increasing frequency of resistance to pesticides by pests is a classical example of evolution at work on a time scale that we can experience directly. Evolution of resistance to a fungicide in populations of plant pathogens is a common phenomenon with important considerations for management of plant diseases (10, $23,31,45)$. A specific pathogen population can evolve resistance when frequency of resistant phenotypes increases as the result of a selection pressure imposed on the population by the use of the fungicide. A necessary condition for selection to occur is that variation in phenotype for resistance exists in the population and that resistant phenotypes exist in at least a low frequency. This selection pressure acts on phenotypes and, thus, on the inheritable genes or quantitative traits controlling the fungicide resistance phenotype. Selection pressure is higher for single genes than for traits controlled by either quantitative trait loci or multiple loci. Individuals in the pathogen population expressing the resistance phenotype increase in frequency when exposed to fungicides. The result of this mechanism of evolution, namely selection, is detected by a shift in the frequency distribution of a particular resistance phenotype coupled with a reduction in genetic diversity.

Evolution of fungicide resistance depends on many factors, including the genetics of resistance in the pathogen. Resistance to fungicides can be based on a single gene or can be polygenic in nature. A single, mitochondrial gene confers resistance to

Corresponding author: N. J. Grünwald

E-mail address: Niklaus.Grunwald@science.oregonstate.edu

DOI: $10.1094 /$ PHYTO-96-1397

This article is in the public domain and not copyrightable. It may be freely reprinted with customary crediting of the source. The American Phytopathological Society, 2006. compared populations from unsprayed plots with populations that had been exposed to several applications of each of the fungicides within a single field season. This study provides novel baseline data and shows that the Toluca valley $P$. infestans population has a wide range of sensitivities to the fungicides fluazinam, cymoxanil, dimethomorph, metalaxyl, and propamocarb. Directional selection toward resistance combined with a reduction in genetic diversity of the $P$. infestans population was observed only for the fungicide metalaxyl. The results obtained provide direct experimental support for continuing vigilance regarding further introductions of exotic strains of $P$. infestans into the United States.

Additional keyword: evolution. strobilurins for the pathogens Mycosphaerella fijiensis, Erysiphe graminis, and Plasmopara viticola (9). In contrast, resistance to metalaxyl in Phytophthora infestans and triadimenol in Pyrenophora teres are controlled by a single chromosomal gene; however, these resistances are further modified by several additional loci $(5,10,24,34,39,40)$.

Evolution to fungicide resistance also depends on potency, persistence and effect, distribution within a crop, and mode of action of a fungicide $(1,4,8,22,25,30,31,41,44)$. Several fungicides belonging to diverse chemical classes are being deployed to control potato late blight. The fungicides included in this study included azoxystrobin, cymoxanil, dimethomorph, fluazinam, metalaxyl-M, and propamocarb hydrochloride. These fungicides are very diverse in terms of mode of action, efficacy, and chemical class. Three of these fungicides are from groups of fungicides considered to be systemic: carbamates (i.e., propamocarb), cymoxanil, and phenylamides (i.e., metalaxyl) (3). The mode of action of propamocarb hydrochloride is not known; however, it has some systemic activity being translocated upward in waterconducting tissues toward new plant growth. Cymoxanil and dimethomorph both are locally systemic and their modes of action are not known. Metalaxyl is a systemic phenylamide that specifically inhibits RNA polymerase. Azoxystrobin has translaminar activity and inhibits respiration (9). Fluazinam uncouples oxidative phosphorylation and is considered to be a protectant fungicide. Mancozeb is a protectant fungicide with multisite inhibitory activity that should result in little or no selection.

We hypothesize that the central highlands of Mexico, being the putative center of origin of Phytophthora infestans (Mont.) de Bary (15), provide a valuable testing ground for evaluating the potential threat of selection for resistance to fungicides. In the Toluca valley, this population reproduces sexually and both 
mating types exist in a $1: 1$ ratio $(6,13,16)$. Genetic diversity for virulence $(32,33,50,51)$, allozyme $(13,49)$, restriction fragment length polymorphism (RFLP) $(13,16)$, and amplified fragment length polymorphism (AFLP) (7) loci is higher in central Mexico than elsewhere in the world. Furthermore, the population has been exposed to many fungicides, including metalaxyl, propamocarb, cymoxanil, mancozeb, and, quite recently, azoxystrobin $(18,19$, $36,37)$. Given that the population is very diverse, has been exposed to fungicides, and is sexual in nature, the chance of detecting selection for resistance within a field season in this population would seem higher than in other locations (15).

The objective of our research was to determine the potential for fungicide resistance selection in the Toluca valley population of $P$. infestans. We specifically tested the hypotheses that exposure to the fungicide would lead to (i) a shift in the sensitivity distributions (i.e., selection) and (ii) a lower genotypic diversity of the population. Our approach was to compare sensitivity on a population that had not been exposed to the fungicide with populations that had been exposed to several applications of each of the fungicides within a single season.

\section{MATERIALS AND METHODS}

Cultural procedures. Field experiments were conducted at the Instituto Nacional de Investigaciones Forestales, Agrícolas y Pecuarias (INIFAP) field station in Metepec, Toluca Valley, in 2000. Whole tubers of cv. Alpha were planted on 22 June. A private company provided Alpha seed tubers. Experimental plots were 10 by $5.5 \mathrm{~m}$ wide (six rows/plot and 16 plants/row). Plots were separated from each other by $4 \mathrm{~m}$. Fertilization and nonexperimental pesticide applications were applied according to standard grower practice in the region as described previously $(18,19)$. Briefly, this practice is that tubers were treated with benomyl (Benlate; $1 \mathrm{~kg}$ a.i./ha) and captan (Captan $50 \mathrm{PH} ; 1 \mathrm{~kg}$ a.i./ha) in the planting hole with a hand sprayer. Fertilizer was applied at time of planting $(\mathrm{N}, 120 \mathrm{~kg} / \mathrm{ha} ; \mathrm{P}, 180 \mathrm{~kg} / \mathrm{ha} ; \mathrm{K}$, $120 \mathrm{~kg} / \mathrm{ha}$; and $\mathrm{Ca}$ and $\mathrm{Mg}, 20 \mathrm{~kg} / \mathrm{ha}$ ) together with the granulated insecticide terbufos (Counter FZ-15; $1.05 \mathrm{~kg}$ a.i./ha). A second fertilizer application ( $60 \mathrm{~kg}$ of $\mathrm{N}$ ) was applied at hilling on 28 July. The herbicide metribuzin (Lexone) was applied at a rate of $525 \mathrm{~g}$ a.i./ha as needed. Several insecticides were applied weekly in rotation as needed (methamidophos, dimethoate, oxamyl, monocrotophos, methomyl, and endosulfan).

Fungicide treatments. Potential for evolution of fungicide resistance within a single field season was evaluated for several active ingredients, including azoxystrobin, cymoxanil, dimethomorph, fluazinam, mancozeb, metalaxyl-M, and propamocarb hydrochloride. Each fungicide was applied to one experimental plot at the rates shown in Table 1 using a backpack sprayer. For all but one fungicide, applications were made at the lowest recommended rate to maximize potential for selection. The exception was the fungicide metalaxyl; we had experience from previous field seasons indicating that the epidemic would progress too rapidly at the lowest recommended rate, so that isolates could not be retrieved at the end of the field season. Thus, we used the highest recommended rate for the metalaxyl treatment (Table 1). The fungicide dimethomorph was available in Mexico only in coformulation with mancozeb (Table 1); thus, the effect of mancozeb and dimethomorph cannot be separated in that treatment. Fungicides were applied every 6 to 11 days (Fig. 1C; application dates are marked by downward-pointing triangles) to allow for a moderate yet sustained epidemic. For logistical reasons, sampling of isolates occurred over several days, which required that the mancozeb and azoxystrobin treatments received an extra application on September 26 (Fig. 1C) to allow sampling isolates that recently had been exposed to the fungicide.

Microclimate and disease progress. Disease severity $(\%)$ was assessed on a plot basis and was estimated visually once to twice per week as described previously $(18,19)$. Air temperature and relative humidity were measured with a shielded thermistor and a sulfonated polystyrene humidity transducer, respectively (207 probe; Campbell Scientific, Logan, UT). The probe was placed at a height of $1.5 \mathrm{~m}$. Rainfall was measured with an automated TE525 tipping bucket rain gage (Texas Instruments, Dallas, TX). The automated CR-10 weather station (Campbell Scientific) was located at approximately $100 \mathrm{~m}$ from the experiment. All sensor signals were sampled in 5-min intervals, and 60-min averages were calculated to enable estimation of hours during which relative humidity was $>90 \%$.

Isolates. Isolates were sampled from single discrete lesions and isolated as described previously (16). By tagging each sampled plant, we avoided sampling the same plant twice. Isolates for the baseline sample before application were obtained on 29 July. Due to the fact that epidemics in fungicide-treated plots did not develop uniformly, isolates sampled after exposure to fungicides had to be collected between 10 September and 9 October as new infections were observed. Thus, all isolates were retrieved from plots that had received at least six fungicide applications. As mentioned above, fungicide applications continued while sampling occurred and all plots received one or two more applications until collections of isolates were complete for each treatment. A period of $24 \mathrm{~h}$ was observed after each spray before isolates were sampled. Isolates were clean cultured by placing a portion of a leaf lesion under a slice of potato tuber $(\approx 0.5 \mathrm{~cm}$ thick) in a petri dish. Tuber slices were obtained from surface-sterilized, healthy tubers of cv. Alpha. Isolation from mycelial tufts on top of the tuber slice was performed 4 to 5 days later by transfer onto selective or regular Rye-A agar (2). Selective Rye A agar was regular Rye-A agar containing the following antibiotics and fungicides: rifampicin at $20 \mathrm{mg} /$ liter, polymyxin $\mathrm{B}$ sulfate at $50 \mathrm{mg} / \mathrm{liter}$, ampicillin at $200 \mathrm{mg} / \mathrm{liter}$, pentachloronitrobenzene (PCNB) at $67 \mathrm{mg} / \mathrm{liter}$, and benomyl at $100 \mathrm{mg} / \mathrm{liter}$.

Fungicide sensitivity. Sensitivities, measured by estimating the effective concentration that inhibited growth by $50 \%\left(\mathrm{EC}_{50}\right)$, were obtained for the population before and after exposure to each fungicide. Each treatment population consisted of 40 to 60 isolates obtained from each experimental plot subjected to one of the fungicide treatments (Table 2). Two independent fungicide assays were conducted to assess the effect of each fungicide on each isolate. Data are expressed as the proportion of radial growth on

TABLE 1. Description of fungicide treatments applied to each 5-by-10-m plot planted with susceptible cv. Alpha ${ }^{\mathrm{a}}$

\begin{tabular}{|c|c|c|c|c|}
\hline Treatment & Active ingredients & Product & Experimental rate (a.i. ha-1) & Recommended rates (a.i. ha ${ }^{-1}$ ) \\
\hline No fungicide & $\ldots$ & & & \\
\hline Mancozeb & Mancozeb $(80 \%)$ & Manzate 200, DuPont & $1.2 \mathrm{~kg}$ & $0.8-3.2 \mathrm{~kg}$ \\
\hline Dimethomorph & Dimethomorph (9\%), Mancozeb (60\%) & Acrobat MZ, Cyanamid & $0.18 \mathrm{~kg}, 1.2 \mathrm{~kg}$ & $0.18-0.27 \mathrm{~kg}, 1.2-1.8 \mathrm{~kg}$ \\
\hline Cymoxanil & Cymoxanil (60\%) & Technical gr., DuPont & $0.16 \mathrm{~kg}$ & $0.16-0.24 \mathrm{~kg}$ \\
\hline Propamocarb & Propamocarb hydrochloride (36\%) & Previcur N, Agrevo & 0.641 & 0.64 liter \\
\hline Metalaxyl & Metalaxyl-M (46.2\%) & Ridomil Gold, Novartis & $0.15 \mathrm{~kg}$ & $0.11-0.15 \mathrm{~kg}$ \\
\hline Azoxystrobin & Azoxystrobin $(22.9 \%)$ & Quadris, Zeneca & $0.05 \mathrm{~kg}$ & $0.05-0.11 \mathrm{~kg}$ \\
\hline Fluazinam & Fluazinam $(40.4 \%)$ & Shogun $500 \mathrm{FW}$, Zeneca & 0.21 & $0.2-0.3$ liter \\
\hline
\end{tabular}

${ }^{a}$ Fungicides were applied at the experimental rate every 6 to 11 days to provide for a moderate but sustained epidemic. 
fungicide-amended medium relative to growth on nonamended medium. Fungicide concentrations used included 0.0, 0.1, 1.0, 10, and $100 \mu \mathrm{g}$ a.i. $\mathrm{ml}^{-1}$. The $\mathrm{EC}_{50}$ was estimated for each isolate from a regression of relative mycelial growth versus the logarithm of fungicide concentration.

Genotypic diversity. Genotypic diversity was estimated by defining a multilocus genotype for each isolate by combining data for mating type and two isozyme loci $(16,17)$. Mating type was determined by pairing each isolate with known A1 and A2 tester strains on Rye-A agar. Oospores forming in a cross of the unknown paired with the A1 tester strain were of the A2 mating type and vice versa. Allozyme genotypes for Glucose-6-phosphate-isomerase (Gpi) (EC 5.3.1.9) and Peptidase (Pep) (EC 3.4.3.1) were determined using cellulose acetate membranes as described previously $(12,16)$.

Statistical analyses. Frequencies of fungicide resistance before and after exposure for each fungicide treatment were compared using Monte Carlo approximations to the two-sided Fisher's exact test, which is appropriate for frequency distributions that include small or zero cell counts (47). Analyses of frequency distributions were performed separately for each fungicide assay and, after determining that the distributions were not significantly different, data were combined for final presentation. Multilocus genotypic diversity analysis for each population distinguished richness, evenness, and diversity as described previously $(16,17)$. Genotypic diversity was calculated as Shannon-Wiener's index $H^{\prime}=$ $-\Sigma_{i} p_{i} \times \ln \left(p_{i}\right)$ (38), where $p_{i}$ is the observed frequency of the $i$ th genotype. The significance of differences between genotypic diversities was calculated for $H^{\prime}$ using a $t$ test (27) with a Bonferroni correction for multiple comparisons. The evenness index $E_{5}(26)$ was calculated as

$$
E_{5}=\frac{(1 / \hat{\lambda})-1}{e^{H^{\prime}}-1}
$$

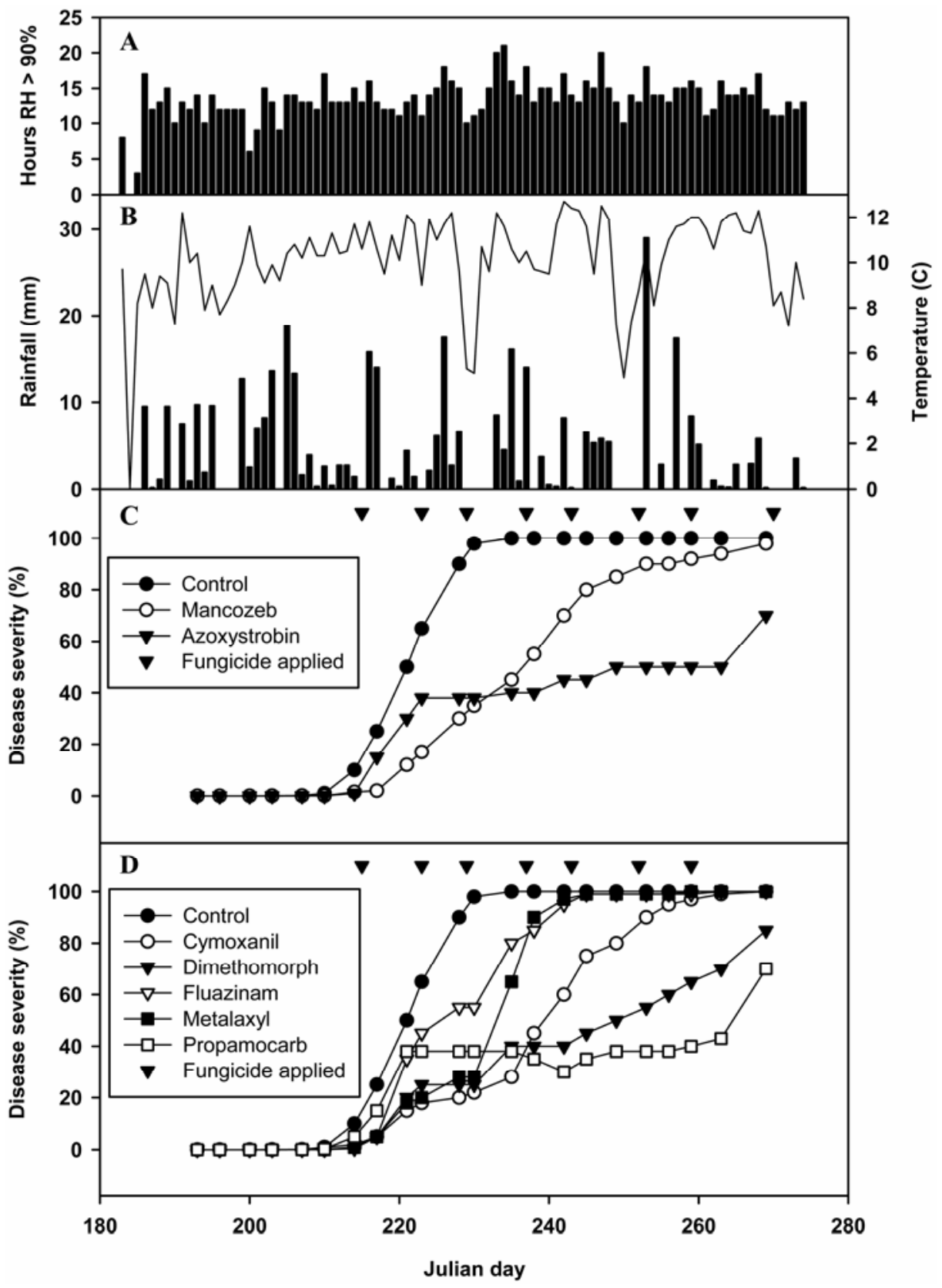

Fig. 1. Dynamics observed during the growing season for A, hours at which relative humidity was above $90 \%$ (Hours $\mathrm{RH}>90 \%)$, B, rainfall (mm) and temperature $\left({ }^{\circ} \mathbf{C}\right)$, and $\mathbf{C}$ and $\mathbf{D}$, disease progress. Dates at which fungicides were applied are marked with downward-pointing triangles; in $\mathbf{C}$, treatments received one more fungicide application than treatments in $\mathbf{D}$. The control did not receive any fungicide application. 
where $\lambda$ corresponds to Simpson's index (43):

$$
\hat{\lambda}=\sum_{i=1}^{g} \frac{n_{i}\left(n_{i}-1\right)}{n(n-1)}
$$

and $n_{\mathrm{i}}$ equals the number of observations of the $i$ th genotype and $n$ equals sample size. Genotypic richness expresses the number of expected genotypes in a sample and was estimated using rarefaction curves based on the sample size of the smallest population using the algorithm $<$ Rarefac.C $>(16,17)$. Bootstrapping of genotypes observed within fungicide-treated populations was conducted using the SAS macro <jackboot.sas> (available online from the SAS Institute, Cary, NC) to calculate confidence intervals for $H^{\prime}(16,17)$. Bootstrapping was conducted using 2,000 resamples at a confidence interval of $95 \%$ using the normal "standard" confidence interval option.

\section{RESULTS}

Environmental conditions were favorable for potato late blight development. Most days had at least $10 \mathrm{~h}$ of relative humidity above $90 \%$, indicating the presence of extended hours of leaf wetness (Fig. 1A). Similarly, average daily temperature was low, ranging between 6 and $12^{\circ} \mathrm{C}$, and rainfall occurred on $68 \%$ of days (Fig. 1B). Disease in the unsprayed control progressed rapidly following an s-shaped pattern without apparent interruptions to the epidemic progress (Fig. 1C and D). The first fungicide application occurred on 2 August (Fig. 1C and D, downward pointing triangles) right after late blight was first observed in the experimental area. Fungicides were applied every 6 to 11 days thereafter at the discretion of the principal investigator (Fig. 1C and D). Disease in all fungicide-treated plots progressed more slowly than in the untreated control. All fungicide-treated plots ended up with $>60 \%$ final disease severity (Fig. 1C and D).

For five of the seven fungicides tested, isolates showing considerable levels of resistance could be detected. With the exceptions of azoxystrobin and mancozeb, isolates able to grow at $>10^{2} \mu \mathrm{g}$ a.i./ml were detected in plots treated with the fungicides cymoxanil, dimethomorph, fluazinam, metalaxyl, and propamocarb hydrochloride (Fig. 2).

Shifts in sensitivity profiles to each of the fungicides after exposure were detected based of Fisher's exact test for four of the seven fungicides (Fig. 2). In case of the fungicides metalaxyl and cymoxanil, the frequency distributions significantly $(P<0.0011$ and 0.0001 , respectively) shifted toward insensitivity as reflected by the median for each population (Fig. 2), indicating directional selection toward resistance. Distributions for the fungicides azoxystrobin and propamocarb hydrochloride also were significantly different $(P<0.0001)$; however, the median of the distributions shifted to the left, making the population after exposure more sensitive to these fungicides. For the fungicides dimethomorph, fluazinam, and mancozeb, no changes in frequency distribution could be detected $(P>0.05)$.

We tested the hypothesis that genotypic diversity would be lowered in a population exposed to the fungicide compared with the unexposed population. Although genotypic diversity based on Shannon-Wiener's index $H^{\prime}$ between fungicide-exposed and baseline populations was significantly different for both the metalaxyl- and the dimethomorph-exposed populations, bootstrap confidence intervals support significant differences for only the metalaxyl-exposed population (Table 2). The baseline sample was somewhat clonal, where 18 genotypes were detected out of 50 isolates evaluated (Table 2). The metalaxyl-exposed population had the lowest expected number of genotypes as estimated by rarefaction, the lowest diversity, and intermediate evenness. The metalaxyl-exposed population became the most clonal, with only nine genotypes recovered from 50 isolates evaluated. However, the evenness in genotype distribution of $E_{5}=0.73$ was similar to that of the baseline population at $E_{5}=0.78$, reflecting that several of the more resistant genotypes were selected.

\section{DISCUSSION}

This study provides novel baseline fungicide sensitivity data for a sexual population of $P$. infestans evaluated in the field at the center of origin under natural growing conditions. The oomycete $P$. infestans has a wide range of sensitivities to the fungicides fluazinam, cymoxanil, dimethomorph, metalaxyl, and propamocarb, with $\mathrm{EC}_{50} \mathrm{~s}$ ranging from $10^{-2}$ to $10^{3} \mu \mathrm{g} \mathrm{ml}^{-1}$, indicating that these fungicides might result in more selection when compared with azoxystrobin and mancozeb, which had comparatively narrow distributions (Fig. 2).

Comparison of our work to previously published reports reveals interesting similarities and differences. The data available from previous studies for the fungicides cymoxanil and metalaxyl showed similar distributions of $\mathrm{EC}_{50}$ values or sensitivities $(11,16$, $28,35,48)$. Resistance to mancozeb and cymoxanil had similar distributions in a Brazilian population of P. infestans (35). The distribution of resistance to dimethomorph in our study overlapped with that of another recent study by Stein and Kirk (46). In contrast, resistance to azoxystrobin in our work ranged between $10^{-3}$ and $10^{-1.5} \mu \mathrm{g} \mathrm{ml}^{-1}$, whereas Gisi et al. (11) found a range of $10^{-2}$ to $10 \mu \mathrm{g} \mathrm{ml}{ }^{-1}$ for isolates collected in Switzerland. Both the Mexican and the Swiss population (11) most likely had not been exposed previously to azoxystrobin. Both studies used a similar range of fungicide concentrations. Our assay relied on relative growth on fungicide amended agar, whereas Gisi et al. (11) used

TABLE 2. Frequencies of multilocus genotypes based on mating type, glucose-6-phosphate isomerase (Gpi) allozyme, and peptidase (Pep) allozyme patterns of isolates of Phytophthora infestans

\begin{tabular}{lccccc}
\hline Population & Sample size & $g^{\mathrm{b}}$ & $g_{30}{ }^{\mathrm{c}}$ & $H^{\prime \mathrm{d}}$ & $E_{5}^{\mathrm{f}}$ \\
\hline Baseline (nonexposed) & 50 & 18 & 14.2 & 2.60 & $2.31-2.89$ \\
Mancozeb & 50 & 17 & 13.8 & 2.55 & $2.25-2.84$ \\
Propamocarb hydrochloride & 51 & 20 & 15.8 & 2.78 & $2.51-3.05$ \\
Cymoxanil & 49 & 15 & 11.8 & 2.21 & $1.85-2.57$ \\
Metalaxyl & 50 & 9 & 7.9 & $1.82^{* *}$ & $1.51-2.12$ \\
Dimethomorph & 30 & 11 & 10.8 & $2.15^{* *}$ & $1.88-2.41$ \\
Azoxystrobin & 60 & 15 & 11.6 & 2.37 & 0.85 \\
Fluazinam & 32 & 13 & 12.6 & 2.30 & $0.73-2.66$ \\
\hline
\end{tabular}

a Sample size was considerable smaller in the dimethomorph and fluazinam treatments because isolates were lost in storage before the assays could be completed.

${ }^{\mathrm{b}}$ Number of multilocus genotypes observed.

${ }^{\mathrm{c}}$ Expected number of multilocus genotypes calculated for a sample size of $n=30$ isolates per population estimated using the rarefaction method (17,42).

${ }^{d}$ Shannon-Wiener diversity index $\left(H^{\prime}\right)$ for multilocus genotypes $(17,38)$. Values followed by $* *$ indicate that $H^{\prime}$ in this population is significantly different $(P<$ 0.01 ) from $H^{\prime}$ of the baseline population according to pairwise, Bonferroni corrected $t$ tests.

${ }^{\text {e }}$ Bootstrap confidence intervals of $H^{\prime}$ based on sample size of 30, using 2,000 resamples, assuming a normal distribution of the sample statistic and a $95 \%$ confidence interval (17).

${ }^{\mathrm{f}}$ Index of evenness for multilocus genotypes $(17,26)$. 
leaf discs from fungicide-treated plants. Thus, the differences between the two studies might relate to a difference in methodology. Another study by Hamlen et al. (20) shows a narrow distribution of resistance to cymoxanil, ranging mostly between $10^{-2}$ to $10^{-1} \mu \mathrm{g} \mathrm{ml}^{-1}$. Our frequency distribution ranged between $10^{-2}$ and $10^{3}$ (Fig. 2). The study by Hamlen et al. (20) used a global population, including isolates from Mexico. Although the abstract mentions both in vitro and in vivo studies, according to the methodology described, their study relied on greenhouse experiments and does not describe in detail how experiments were conducted and how $\mathrm{EC}_{50}$ values were calculated (20). Thus, the differences observed between our results and those by Hamlen et al. again might be due to methodological differences. Based on their results, Hamlen et al. (20) concluded that, worldwide, the population of $P$. infestans is sensitive to cymoxanil. Our results indicate that the resistance spectrum is broad and includes isolates resistant to cymoxanil.

We detected directional selection toward higher resistance only for the fungicides metalaxyl and cymoxanil. Only in the case of metalaxyl did we also detect a significant reduction in genotypic diversity based on Bonferroni adjusted $t$ tests. The significant shifts in the distributions of azoxystrobin and propamocarb toward more sensitivity were not expected. We expected to detect either positive selection toward more resistance, as was the case
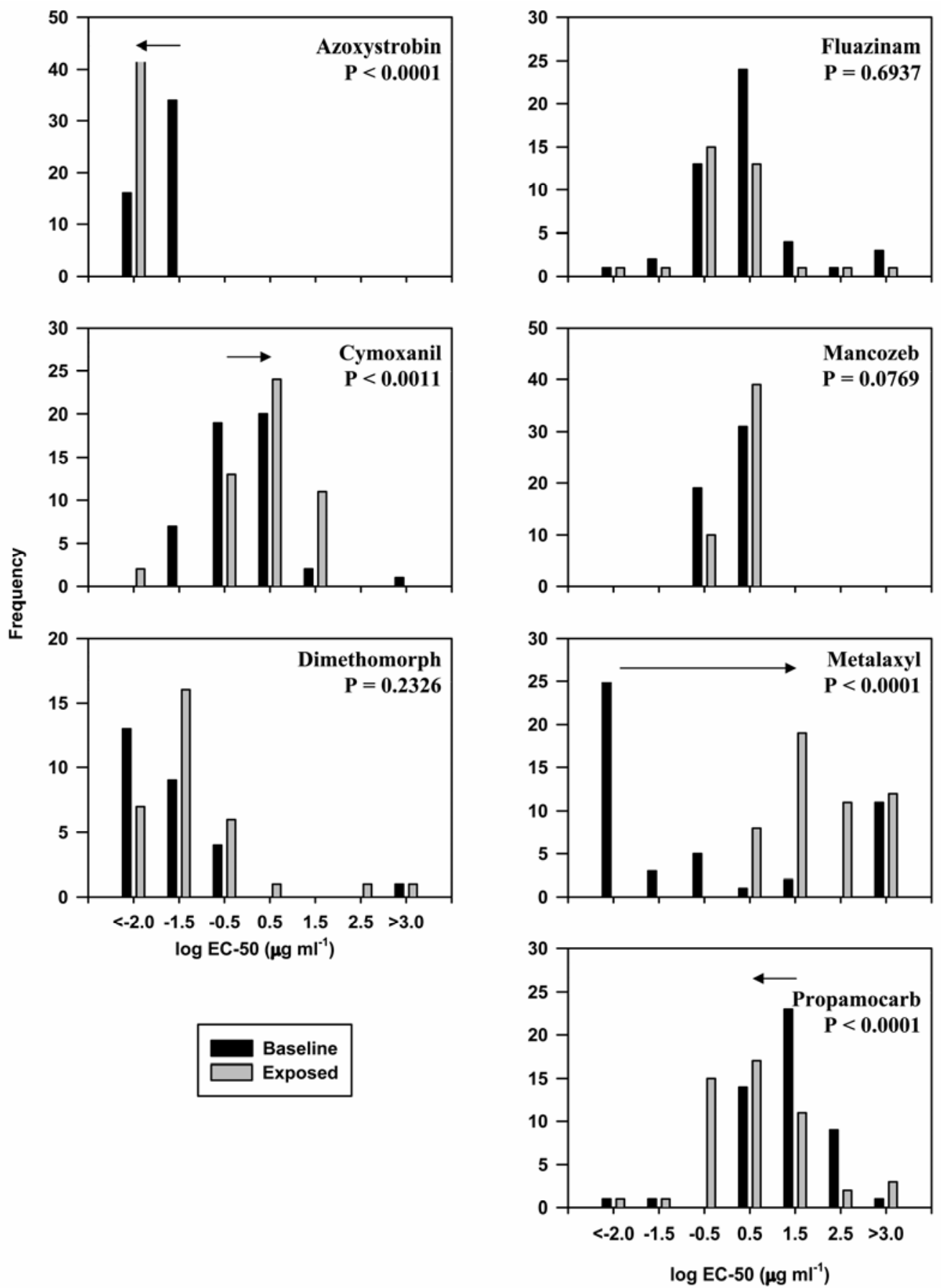

Fig. 2. Distribution of the logarithm of effective concentration that inhibited growth by $50 \%\left(\mathrm{EC}_{50}\right)$ values before and after exposure of the Phytophthora infestans population to different fungicides. Classes of sensitivity were based on the logarithm of $\mathrm{EC}_{50}$ values and defined as follows: $\leq-2.0,>-2.0$ to $\leq-1.0,>-1.0$ to $\leq 0.0$, $>0.0$ to $\leq 1.0,>1.0$ to $\leq 2.0,>2.0$ to $\leq 3.0$, and $>3.0 \mu \mathrm{g} \mathrm{m}{ }^{-1}$. The two-sided probability values given were determined using a Monte Carlo approximation to the Fisher's exact test for $\mathrm{s} \times \mathrm{r}$ tables contrasting the frequency distributions for baseline and exposed populations for each fungicide. The arrows indicate the direction (and approximate magnitude) of a statistically significant shift in median from distributions before and after exposure of the population to a fungicide. 
for metalaxyl and cymoxanil, or no selection, as was the case for three of the fungicides, including fluazinam, mancozeb, and dimethomorph. Several explanations are possible for these observations. In both cases, the frequency distributions before and after exposure were compared using a Fisher's exact test to detect shifts in the median (and overlap of the range of values). In the case of azoxystrobin, the distribution of $\mathrm{EC}_{50}$ values was located at the lower end of the detection threshold; thus, our assay was at the limit of the range at which we could reasonably expect to describe a distribution of fungicide resistance. It is apparent that, for the methodology used, azoxystrobin sensitivity needs to be evaluated using fungicide concentrations lower than $0.1 \mu \mathrm{g}$ a.i. $\mathrm{ml}^{-1}$. In the case of propamocarb, the situation is quite different, and no straightforward explanation comes to mind. The distributions before and after exposure cover the full range of $\mathrm{EC}_{50}$ values and both distributions overlap over the whole range.

The fact that selection for fungicide resistance could not be detected within a field season for azoxystrobin, dimethomorph, fluazinam, and propamocarb does not mean that resistance could not evolve. Evolutionary forces such as mutation, migration, and random drift (31) cannot be expected to be detected within a single field season in small experimental plots and with a very small sample size ( $\approx 50$ isolates) unless these forces are very strong. In analogy to the durability of resistance of a host to a pathogen, "durability" of a fungicide can be evaluated only over long periods of time and large areas $(14,21)$. This also is reflected in the unexpected result that we actually detected a shift toward susceptibility in the dimethomorph-treated populations relative to baseline samples.

Experiments were performed in experimental plots and, thus, the baseline population sampled would be expected to be less diverse relative to a sample representing the diversity found in the valley overall. A comparison to our previous work using the exact same methodology for determining multilocus genotypes based on mating type, Gpi, and Pep loci reveals that the genotypic diversity in the baseline sample was indeed lower $\left(H^{\prime}=2.6\right)$ relative to a larger, hierarchical population sample representative of the Toluca Valley overall $\left(H^{\prime}=2.8\right.$ to 3.1$)(16,17)$.

Given that the Mexican population of $P$. infestans contains individuals at frequencies $>2 \%$ (i.e., 1 in 50 isolates) that have been shown to have $\mathrm{EC}_{50}$ values $>100 \mu \mathrm{g}$ a.i. $\mathrm{ml}^{-1}$ to cymoxanil, dimethomorph, fluazinam, metalaxyl, and propamocarb (Fig. 2), further introductions of novel clones from Mexico should be avoided. The situation is quite different for azoxystrobin, where all isolates evaluated were sensitive. Expected risk of evolution of fungicide resistance is determined by the evolutionary potential of $P$. infestans (29). Given that $P$. infestans has a mixed reproductive system, a high potential for genotype flow (through human activity), a moderate to large effective population size, and baseline populations that already have insensitive isolates, it has to be considered to be a high-risk pathogen for evolution of fungicide resistance (29). Establishment and clonal reproduction of strains tolerant to cymoxanil, dimethomorph, fluazinam, and propamocarb could lead to a situation analogous to that of metalaxyl. The results obtained provide direct experimental support for continuing vigilance regarding further introductions of exotic strains of $P$. infestans into the United States.

\section{ACKNOWLEDGMENTS}

Programa Internacional Cooperativo del Tizón Tardío de la Papa (PICTIPAPA), the Cornell-Eastern Europe-Mexico (CEEM) Potato Late Blight Project, ZENECA (now Syngenta), and the USDA-ARS provided funding to support this work. We thank PICTIPAPA for the use of their infrastructure; Instituto de Investigación y Capacitación Agropecuaria, Acuícola y Forestal del Estado de México (ICAMEX) for providing us with research equipment and laboratory facilities, as well as conducting tractor work for our field plots; INIFAP for supplying us with research equipment, providing land, and helping with tractor work; R. Coria (DuPont) for supplying cymoxanil; and G. Olaya (Zeneca) for supplying azoxystrobin. Data for the fungicides metalaxyl and cymoxanil were presented previously in a review article as unpublished data (15).

\section{LITERATURE CITED}

1. Bruck, R. I., Fry, W. E., Apple, A. E., and Mundt, C. C. 1981. Effect of protectant fungicides on the developmental stages of Phytophthora infestans in potato foliage. Phytopathology 71:164-166.

2. Caten, C. E., and Jinks, J. L. 1968. Spontaneous variability of single isolates of Phytophthora infestans. I. Cultural variation. Can. J. Bot. 46:329-348.

3. Cohen, Y., and Coffey, M. D. 1986. Systemic fungicides and the control of oomycetes. Annu. Rev. Phytopathol. 24:311-338.

4. Doster, M. A., Milgroom, M. G., and Fry, W. E. 1990. Quantification of factors influencing potato late blight suppression and selection for metalaxyl resistance in Phytophthora infestans: A simulation approach. Phytopathology 80:1190-1198.

5. Fabritius, A. L., Shattock, R. C., and Judelson, H. S. 1997. Genetic analysis of metalaxyl insensitivity loci in Phytophthora infestans using linked DNA markers. Phytopathology 87:1034-1040.

6. Flier, W. G., Grünwald, N. J., Fry, W. E., and Turkensteen, L. J. 2001. Formation, production and viability of oospores of Phytophthora infestans isolates from potato and Solanum demissum in the Toluca Valley, central Mexico. Mycol. Res. 105:998-1006.

7. Flier, W. G., Grünwald, N. J., Kroon, L. P. N. M., Sturbaum, A. K., van den Bosch, G. B. M., Garay-Serrano, E., Fry, W. E., and Turkensteen, L. J. 2003. The population structure of Phytophthora infestans from the Toluca Valley in central Mexico suggests genetic differentiation between populations from cultivated potato and wild Solanum species. Phytopathology 93:382-390.

8. Fry, W. E., and Milgroom, M. G. 1988. The population biology and management of fungicide resistance. Abstr. Pap. Am. Chem. Soc. 196:275-285.

9. Gisi, U., Chin, K. M., Knapova, G., Küng Färber, R., Mohr, U., Parisi, S., Sierotzki, H., and Steinfeld, U. 2000. Recent developments in elucidating modes of resistance to phenylamide, DMO and strobilurin fungicides. Crop Prot. 19:863-872.

10. Gisi, U., and Cohen, Y. 1996. Resistance to phenylamide fungicides: a case study with Phytophthora infestans involving mating type and race structure. Annu. Rev. Phytopathol. 34:549-572.

11. Gisi, U., Hermann, D., Ohl, L., and Steden, C. 1997. Sensitivity profiles of Mycosphaerella graminicola and Phytophthora infestans populations to different classes of fungicides. Pestic. Sci. 51:290-298.

12. Goodwin, S. B., Schneider, R. E., and Fry, W. E. 1995. Use of celluloseacetate electrophoresis for rapid identification of allozyme genotypes of Phytophthora infestans. Plant Dis. 79:1181-1185.

13. Goodwin, S. B., Spielman, L. J., Matuszak, J. M., Bergeron, S. N., and Fry, W. E. 1992. Clonal diversity and genetic differentiation of Phytophthora infestans populations in northern and central Mexico. Phytopathology 82:955-961.

14. Grünwald, N. J., Cadena Hinojosa, M., Rubio Covarrubias, O. A., Rivera Peña, A., Niederhauser, J. S., and Fry, W. E. 2002. Potato cultivars from the Mexican national program: Sources and durability of resistance against late blight. Phytopathology 92:688-693.

15. Grünwald, N. J., and Flier, W. G. 2005. The biology of Phytophthora infestans at its center of origin. Annu. Rev. Phytopathol. 43:171-190.

16. Grünwald, N. J., Flier, W. G., Sturbaum, A. K., Garay-Serrano, E., van den Bosch, T. B. M., Smart, C. D., Matuszak, J. M., Lozoya-Saldaña, H., Turkensteen, L. J., and Fry, W. E. 2001. Population structure of Phytophthora infestans in the Toluca Valley region of Central Mexico. Phytopathology 91:882-890.

17. Grünwald, N. J., Goodwin, S. B., Milgroom, M. G., and Fry, W. E. 2003. Analysis of genotypic diversity data for populations of microorganisms. Phytopathology 93:738-746.

18. Grünwald, N. J., Romero Montes, G., Lozoya Saldaña, H., Rubio Covarrubias, O. A., and Fry, W. E. 2002. Potato late blight management in the Toluca valley: Field validation of SimCast modified for cultivars with high field resistance. Plant Dis. 86:1163-1168.

19. Grünwald, N. J., Rubio-Covarrubias, O. A., and Fry, W. E. 2000. Potato late-blight management in the Toluca Valley: Forecasts and resistant cultivars. Plant Dis. 84:410-416.

20. Hamlen, R. A., and Power, R. J. 1998. Distribution of sensitivity response to cymoxanil within global populations of Phytophthora infestans. Pestic. Sci. 53:101-103.

21. Johnson, R. 1984. A critical analysis of durable resistance. Annu. Rev. Phytopathol. 22:309-330.

22. Knight, S., C, Anthony, V. M., Brady, A., M, Greenland, A. J., Heaney, S. P., Murray, D. C., Powell, K. A., Schulz, M. A., Spinks, C. A., 
Worthington, P. A., and Youle, D. 1997. Rationale and perspectives on the development of fungicides. Annu. Rev. Phytopathol. 35:349-372.

23. Köller, W., and Scheinpflug, H. 1987. Fungal resistance to sterol biosynthesis inhibitors: a new challenge. Plant Dis. 71:1066-1074.

24. Lee, T. Y., Mizubuti, E. S. G., and Fry, W. E. 1999. Genetics of metalaxyl resistance in Phytophthora infestans. Fungal Genet. Biol. 26:118-130.

25. Levy, Y., Levy, R., and Cohen, Y. 1983. Build up of a pathogen subpopulation resistant to a systemic fungicide under various control strategies: A flexible simulation model. Phytopathology 73:1475-1480.

26. Ludwig, J. A., and Reynolds, J. F. 1988. Statistical Ecology: A Primer on Methods and Computing. John Wiley \& Sons, New York.

27. Magurran, A. E. 1988. Ecological Diversity and Its Measurement. Princeton University Press, Princeton, NJ.

28. Matuszak, J. M., Fernandez Elquezabal, J., Villarreal Gonzalez, M., and Fry, W. E. 1994. Sensitivity of Phytophthora infestans populations to metalaxyl in Mexico: Distribution and dynamics. Plant Dis. 78:911-916.

29. McDonald, B. A., and Linde, C. 2002. Pathogen population genetics, evolutionary potential, and durable resistance. Annu. Rev. Phytopathol. 40:349-379.

30. Milgroom, M. G., and Fry, W. E. 1988. A simulation analysis of the epidemiological principles for fungicide resistance management in pathogen populations. Phytopathology 78:565-570.

31. Milgroom, M. G., Levin, S. A., and Fry, W. E. 1989. Population genetic theory and fungicide resistance. Pages 340-367 in: Plant Disease Epidemiology, K. J. Leonard and W. E. Fry, eds. McGraw Hill, New York.

32. Mills, W. R., and Niederhauser, J. S. 1953. Observations of races of Phytophthora infestans in Mexico. Phytopathology 43:454-455.

33. Niederhauser, J. S., Cervantes, J., and Servin, L. 1954. Late blight in Mexico and its implications. Phytopathology 44:406-408.

34. Peever, T. L., and Milgroom, M. G. 1993. Genetic correlations in resistance to sterol biosynthesis-inhibiting fungicides in Pyrenophora teres. Phytopathology 83:1076-1082.

35. Reis, A., Ribeiro, F. H. S., Maffia, L. A., and Mizubuti, E. S. G. 2005. Sensitivity of Brazilian isolates of Phytophthora infestans to commonly used fungicides in tomato and potato crops. Plant Dis. 89:12791284.

36. Rubio-Covarrubias, O. A., and Flores-Gutiérrez, F. X. 1997. Programa nacional de investigación en el cultivo de la papa. Instituto Nacional de Investigaciones Forestales, Agrícolas y Pecuarias (INIFAP), Mexico City.

37. Rubio Covarrubias, O. A., Rivera Peña, A., Rangel González, J. A., Cadena Hinojosa, M., Flores López, R., Rocha Rodríguez, R., Magallanes González, J. V., Ortíz Trejo, C., Díaz Hernandez, C., López Delgado, H.,
Zavala Quintana, T. E., Díaz Valasis, M., and Paredes Tenorio, A. 2000. Manual para la Producción de Papa en las Sierras y Valles Altos del Centro de México. Instituto Nacional de Investigaciónes Forestales, Agrícolas y Pecuarias, Zinacantepec, Estado de México, México.

38. Shannon, C. E., and Weaver, W. 1949. The Mathematical Theory of Communication. University of Illinois Press, Urbana.

39. Shattock, R. C. 1986. Inheritance of metalaxyl resistance in the potato late-blight fungus. Proc. Br. Crop Prot. Soc. 2:555-560.

40. Shattock, R. C. 1988. Studies on the inheritance of resistance to metalaxyl in Phytophthora infestans. Plant Pathol. 37:4-11.

41. Shaw, M. W. 1989. Theoretical analysis of the effect of interacting activities on the rate of selection for combined resistance to fungicide mixtures. Crop Prot. 12:120-126.

42. Simberloff, D. 1979. Rarefaction as a distribution-free method of expressing and estimating diversity. Pages 159-176 in: Ecological Diversity in Theory and Practice. J. F. Grassle, G. P. Patil, W. Smith, and C. Taillie, eds. International Co-operative Publishing House, Fairland, MD.

43. Simpson, E. H. 1949. Measurement of diversity. Nature 163:688.

44. Skylakakis, G. 1981. Effects of alternating and mixing pesticides on the buildup of fungal resistance. Phytopathology 71:1119-1121.

45. Staub, T. 1991. Fungicide resistance: Practical experience with antiresistance strategies and the role of integrated use. Annu. Rev. Phytopathol. 29:421-442.

46. Stein, J. M., and Kirk, W. W. 2004. The generation and quantification of resistance to dimethomorph in Phytophthora infestans. Plant Dis. 88:930934.

47. Stokes, M. E., Davis, C. S., and Koch, G. G. 1995. Categorical Data Analysis Using the SAS System. SAS Institute, Inc., Cary, NC.

48. Sujkowski, L. S., Fry, B. A., Power, R. J., Goodwin, S. B., Peever, T. L., Hamlen, R. A., and Fry, W. E. 1995. Sensitivities of Mexican isolates of Phytophthora infestans to chlorothalonil, cymoxanil, and metalaxyl. Plant Dis. 79:1117-1120.

49. Tooley, P. W., Fry, W. E., and Villareal-Gonzalez, M. J. 1985. Isozyme characterization of sexual and asexual Phytophthora infestans populations. J. Hered. 76:431-435.

50. Tooley, P. W., Sweigard, J. A., and Fry, W. E. 1986. Fitness and virulence of Phytophthora infestans isolates from sexual and asexual populations. Phytopathology 76:1209-1212.

51. Turkensteen, L. J. 1993. Durable resistance of potatoes against Phytophthora infestans. Pages 115-124 in: Durability of Disease Resistance. T. Jacobs and J. E. Parlevliet, eds. Kluwer Academic Press, Dordrecht, The Netherlands. 